Meta

Journal des traducteurs

Translators' Journal

\title{
Interpreting Errors in Translation
}

\section{Candace Séguinot}

Volume 35, numéro 1, mars 1990

Actes du colloque international " La traduction proligère "

URI : https://id.erudit.org/iderudit/004078ar

DOI : https://doi.org/10.7202/004078ar

Aller au sommaire du numéro

Éditeur(s)

Les Presses de l'Université de Montréal

ISSN

0026-0452 (imprimé)

1492-1421 (numérique)

Découvrir la revue

Citer cet article

Séguinot, C. (1990). Interpreting Errors in Translation. Meta, 35(1), 68-73.

https://doi.org/10.7202/004078ar d'utilisation que vous pouvez consulter en ligne.

https://apropos.erudit.org/fr/usagers/politique-dutilisation/ 


\section{INTERPRETING ERRORS IN TRANSLATION}

CANDACE SÉGUINOT

York University, Toronto, Canada

\section{INTRODUCTION}

Sometimes I happen to reread a translation after I've submitted it to a client, and there it is: an elegant solution to a translation problem, obvious now, but not obvious then. At times like these I like to remember a story one of my colleagues told me about a well-known and highly respected interpreter. The meeting for which he was interpreting was about the provision of public services. At one point in the discussion someone brought up the question of authority for the public washroom facilities at the yacht basin. These facilities were so poorly maintained, the speaker lamented, that sailors could not use them, preferring to moon out over the sides of their boats. On hearing the term moon out, the interpreter grew glassy-eyed and offered the French-speaking members of his audience the totally meaningless et ils préfèrent faire de la lune par-dessus leurs voiliers.

I cherish this story partly because it makes me feel better personally, and because it illustrates several points about errors. First of all, even excellent translators and interpreters make horrific mistakes. Secondly, some errors are almost unavoidable given the fact that translators and interpreters inevitably have vocabulary and knowledge gaps, gaps which cannot always be filled in time. Hence the third point, that evaluating the seriousness of an error is a less interesting exercise than interpreting the source of an error. Errors obviously tell us something about the quality of a translation, but they are also windows into the translating process itself. Analysis of slips of different kinds has been used in linguistics to provide evidence about the organization of mental grammars (for example Cutler 1982 and Fromkin 1980) and to postulate intermediate grammars or interlanguage in the language learner. In the same way, translation errors provide two kinds of information: an indication of how information about language might be organized in the brain and an insight into the developmental process that takes place in translator training.

\section{ERRORS IN TRANSLATION AND IN INTERPRETATION}

One of the first questions one could ask is whether errors reveal any differences between translating and interpreting. A recent article by Wolfgang Lörscher (1987: 436) expresses an attitude which seems to be representative of translation theorists: "The concept of a translational expectation structure, as far as it refers to translational problems, is largely built up by separating SL forms from their meanings. Such separating has been described by Seleskovitch $(1976: 103,1978: 336)$ in connection with the process of interpreting and is assumed to be operating also in the process of translation." Marianne Lederer (1981: 131, 334-336) has also suggested that the interference problems caused by working in two languages are the same in translation as in interpretation. Yet the pragmatic aspects of translating and interpreting are different: the translator has the luxury of being able to revise his or her work. The translator, on the other hand, is sometimes subject to constraints on the length and formatting of texts when the target version is to be published side-by-side with the original, and may be working to a given production quota. It's not all that obvious, in other words, that the strategies used in an activity 
composed of reading and writing would be identical to those used in an activity based on listening and speaking, and that the errors specific to the use of strategies would be exactly the same.

And here it seems necessary to make the distinction between what people should do, and what they do do. Whether or not translations would be better if people translated as they interpreted is one question. However, the fundamental principle of empirical research is that if people consistently perform in a given way, there is a heuristic behind that behaviour. The goal of empirical research is to discover that heuristic.

From this perspective, there is some evidence that professional translators may develop strategies that are not quite the same as the interpreter's. In fact, if we use Marianne Lederer's (1981: 129, 237) description of the interpreter who transcodes until there is a déclic and then begins to truly interpret, the process might be described as the reverse. The examples come from an observational study of a professional translator working in the office at the Secretary of State (Séguinot: 1989). Excerpts of the source and target texts are provided in the Appendix. In this study, I found that the types of errors that the translator made at the beginning of sentences were not the same as the errors toward the end of the sentence. For example, in the paragraph labelled 4 in the texts, the singular in French cette visite is rendered in English by the more idiomatic plural, but later in the sentence, le code postal and la mécanisation are produced in the singular and then corrected. The typing error in the French text in paragraph 7 is clearly the source of the typing error in the English text, which indicates that the translator was dealing with the written form of the words on the page at that point. There are several examples where the translator had not come to terms with post-posed constructions in French that need to be pre-posed in English. One example on the handout is in paragraph 6, the six caracteres. What these kinds of errors show is that the translator was working more closely with the written text near the ends of sentences. A plausible explanation for this finding is that the act of translating creates a kind of self-propelling impulse like the act of writing. At the same time the translator has to work with the constraints of short-term memory. When that memory begins to fade, the translator may turn to transcoding.

\section{THE ORGANIZATION AND ACCESSING OF INFORMATION}

What does this show about the way information is organized and accessed? For one thing, the ability to translate is clearly not simply a case of developing automatic connections between items and structures in two languages. The likelihood of there being interference from the source language may vary according to the positioning of the items and information in a sentence.

These kinds of errors are interesting in that they may represent specific translation errors, i.e., errors that would not occur in spontaneous native language production. It is also interesting that working with a source text induces errors under the influence of the source language morphology, whereas in spontaneous second language production, the native morphological system of language learners tends to interfere with knowledge of the second language system.

Translators and interpreters also monitor their output differently. The professional translators that I have studied correct most of their spelling and typing errors as they produce their translations. This means that translators must be able to access specific kinds of information without triggering all the information available about the words or concepts being monitored. The fact that translators leave decisions about style and lexical choice to some kind of natural revision point but are able to correct surface errors immediately indicates that there may be less processing capacity used in these activites, so they can be carried on at the same time as the translation. 
The retrieving of lexical items from memory has received a certain amount of attention in the translation literature. Marianne Lederer (1973: 22-23), speaking of interpretation, has suggested that "Lorsque les mots ont une ressemblance formelle dans les deux langues, le réflexe pousse à conserver le même mot; lorsque leurs formes diffèrent, on traduit le sens premier." Jiři Levý (1965: 78) put forward a different principle, namely that the translator tends to choose a general term over equivalent terms because it will come to his or her mind first. Hypotheses about translation based on observations of student or non-professional translators provide a third explanation: Hans Krings (1986: 271), referring to students with little translation experience has said that "The most important retrieval strategy involved in translation seemed to be the recall of fixed interlingual associations."

\section{THE DEVELOPMENT OF TRANSLATION SKILLS}

Do translation students, as the paragraph above suggests, use different strategies from professional translators? Can they learn to use professional strategies in school, or do some strategies only develop with practice? One of my colleagues, Christine KleinLataud, and I have been collecting data for five years in a longitudinal study of the students in the translation programme at our university. These students have five half-courses translating into their native language over the course of their three years of study. At the start of their fall course and at the end of their winter course they have been given a test made up of excerpts from a magazine article that appeared in French and English versions. There were two related texts for each of the language groups with a third test made up of parts of the other two. Students were given one hour for the test, and allowed to use dictionaries. They were asked to make changes in such a way that we could still read the original choices - crossing out or rewriting.

We now have information on 151 students. To date, part of the comparison has been completed involving an analysis of the work of the very best students, which includes our gold medal winners and some students who were already professional translators, and the worst students, or rather those who managed to scrape by to their last year, since students who did not make it through the programme would not have completed the series of tests.

The good news first: it is obvious which errors characterize the poor translation student as opposed to the good translation student. Grammar errors in the first language are the clearest sign: for Anglophone students mistakes like subject-verb agreement, for Francophones the past participle and infinitive confused. That, in fact, is an error which may signal that the student is accessing words, and by extension morphemes, phonetically rather than semantically, and that there is limited comprehension of the source language, limited vocabulary, and word-bound translation skills.

One of the more interesting errors on the part of one of the weak Anglophone students is reproduced below:

\section{French text}

La superficie qu'on y consacre aux jardins particuliers, aux parterres municipaux, aux lopins loués pour la culture, aux parcs, aux squares, aux plates-bandes autour des écluses et

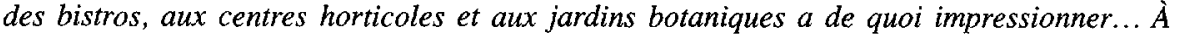
telle enseigne que l'histoire de ces tisserands du Lancashire en devient vraisemblable: ces gens auraient, ...

\section{Translation: Poor student, 4th year}

The surface area of the various types of gardens, municipal flower beds, cultural gardens, parks, squares, and flower beds around bars and bistros is quite impressing, so much so that ... 
Where does the impressing come from? It could be the kind of slip known as a blend, but of impressive and what? It could also be that this student has rephrased the information in the source language text to capture the simplified meaning, something like est impressionnant. The simplification of the language of the source text is one of the strategies described by Wolfgang Lörscher (424-428) in his observation of students verbally translating texts.

The bad news is that the difference between the gifted students and the weak ones is greater than the differences in skills developed through the programme, at least with these two groups. What is interesting in terms of errors is the performance of the very good students, because by fourth year most of these students will have had professional experience in a stage placement and some will already be working as translators. There is some evidence that certain students do begin to make more changes near the end of sentences than at the beginning, which might indicate that they were working more with memory in the first part of the sentence. However, what is unexpected is that some of the texts produced by the graduating students were actually worse than the translations they produced in earlier years. The example below shows the translation of the same part of the French text reproduced earlier translated this time by one of the better Anglophone students, followed by an illustration of the same kind of phenomena in a Francophone student:

\section{Translation: Good student, first course in translation}

The space devoted there in England to private gardens, town flowerbeds, plots of land rented for cultivation, parks, public gardens, flowerbeds around locks (?) and pubs, horticultural centres and botanical gardens is quite impressive.

So much so that the story ...

\section{Same student, fourth year}

The area set aside for special gardens, municipal flowerbeds plots of land rented for cultivation, parks, squares, beds surrounding canals and bistros, horticultural centres and botanical gardens is quite impressive. So much so that the history of these Lancashire weavers is likely quite true:

\section{English text}

But the inspirational source for the private garden is found in the public showplaces - gardens of genius on a large scale.

\section{Translation: Good student, first course in translation}

Cependant, la source inspirationnelle pour le jardin privé se trouve dans les expositions publiques - jardins fabuleux à grande échelle.

\section{Same student, third year}

Mais la source d'inspiration des jardins privés se trouventans les lieux grands intérêt touristique - jardins de génie à grande échelle.

\section{Same student, fourth year \\ Text}

All of which lends great credence to stories about the 18th century Lancashire weavers who formed intensely competitive groups, each trying to grow the perfect primula.

\section{Translation}

Tous ajoutent foi aux histoires des - tisserands du Lancashire cours du a voulant que, au XVIII ${ }^{\mathrm{e}}$ siècle, formaient des groupes faisaient compétition pour faire pousser la primevère parfaite. 
The Anglophone student translates words like particulier and bistro appropriately in first year, but translates incorrectly, clearly influenced by the words in the source text, in her last year. The Francophone student in third year makes mistakes in number agreement. If we look at what students do well in these translations, however, there is a possible explanation for the increase in errors. For both students, the syntax of the texts produced in later years is an improvement on the syntax of the first translations. In fourth year the Francophone student is particularly attentive to the style of the text. It may be, therefore, that students as they are learning begin to attend to different facets of language.

Translation students are the product of language courses, and it is natural that as beginners they apply the strategies appropriate to their language courses. This, rather than the nature of the translating process, would explain why students first try out fixed associations. The better students try to apply the principles they learn in their translation classes. However, they may not have enough experience to be able to automatically monitor their work for surface errors at the same time as they translate. Given the fact that processing capacity is limited, it would make sense that concentrating consciously on some aspect of language would mean less attention paid to other aspects, and therefore the possibility of a student making different kinds of errors at different stages of development. In a sense, then, the fact that certain students make errors is encouraging. University provides the food for reflection, and the fact that errors appear in conjunction with specific improvements is an indication that that reflection is taking place. There is little indication that the positioning of information changes the kind of errors students make, so the kind of distinction found in the study of the professional translator probably arises where experienced translators have developed a rhythm to cope with the volume of work.

\section{REFERENCES}

CUTLER, Anne (1982): "The Reliability of Speech Error Data", in Anne Cutler (ed.), Slips of the Tongue, Amsterdam, Walter de Gruyter, pp. 7-28.

FROMKIN, Victoria A.(ed.) (1980): Errors in Linguistic Performance. Slips of the Tongue, Ear, Pen, and Hand, New York, Academic Press.

KRINGS, Hans (1986): “Translation Problems and Translation Strategies of Advanced German Learners of French (L2)", in J. House and S. Blum-Kulka (eds.), Interlingual and Intercultural Communication, Tübingen, Gunter Narr, pp. 263-276.

LEDERER, Marianne (1973): "La traduction : Transcoder ou réexprimer?" Études de linguistique appliquée, Y. 12 , pp. 8-25.

LEDERER, Marianne (1981): La Traduction simultanée, Paris, Minard.

LEVY, Jiri (1965): "Will Translation Theory Be of Use to Translators?" in R. Italiaander (ed.), Überstzen, Vorträge und Beiträge vom Internationalen Kongress literarischer $\ddot{U} b e r s t e t z e r ~ i n ~ H a m b u r g ~ 1965$, Frankfurt am Main, Bonn, Athenäum, pp. 77-82.

LÖRSCHER, Wolfgang (1987): "On Analyzing Translation Performance", in W. Lörscher and R. Schulze (eds.), Perspectives on Language in Performance, Tübingen, Gunter Narr, pp. 424-440.

SÉGUINOT, Candace (1989): "The Translation Process: An Experimental Study", in C. Séguinot (ed.), The Translation Process, Toronto, H. G. Publications, York University.

SELESKOVITCH, Danica (1976): Langage, Langues et Mémoire, Paris, Minard. 


\section{APPENDIX}

Professional Translator

Source Text

3 Une équipe de Postes Canada a visité pendant deux ans quelque quatorize pays : Australis, Russie, Hollande, NouvelleZélande, Gance, Angleterre, Belgique, États-Unis et même le Japon.

4 Le but de cette visite était de $s^{\prime}$ informer et de recueillir des données sur le code postallet la mécanisation existantel dans ces pays.

5 Une firme de consultants fut engagée pour étudier la documentation et faire des suggestions sur l'implantation d'un code postal et de la mécanisation au pays.

6 Les consultants sugqèrent un code alpha-numérique qu'on appelle ANA NAN, six caractères.

7 En comparant le ZIP code américain où les possibilités sont de 99,999, vous remarquerez qu'au Canada, les possibilités peuvent atteindre $8,000,000$ avec le code alpha-nymerique.

Professional Translator

Target Text

3

Over a portod of two years a teum from the Canada Post office

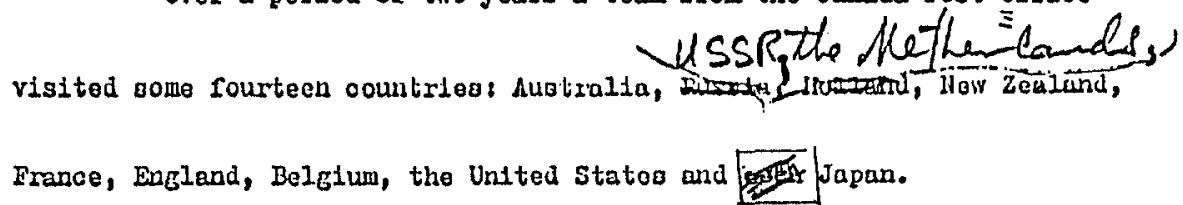

The purpose of thege vialte was to gathor Information and taxk

data on the postal codes and the existing mechanization in these countriea.

A confoulting firm was engaged to otudy the docunentation and

make sugceotions on tho 1mplementation of a postal oode and mix mechanization

In the oountry.

7

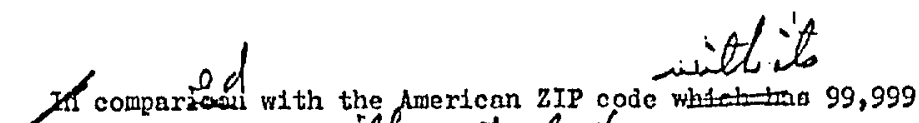
you will rete $z \ell_{c-} f$

possible combinations, the Canadian alphe-nyumerte code has

0,000,000/combinationa. 